\title{
Pairing season habitat selection by Montezuma quail in southeastern Arizona
}

\author{
KIRBY D. BRISTOW AND RICHARD A. OCKENFELS
}

Authors are Associate Research Biologist and Research Program Supervisor, Arizona Game and Fish Department, 2221 W. Greenway Rd., Phoenix, Ariz 85023.

Abstract

Montezuma quail (Cyrtonyx montezumae Vigors) are closely associated with oak woodlands (Quercus spp.). Livestock grazing and cover availability are considered important factors affecting Montezuma quail distribution and density. While habitat conditions during pairing season (April-June) are thought to be important to Montezuma quail survival and reproduction, information on habitat selection during that time is limited. We investigated habitat selection by Montezuma quail in grazed and ungrazed areas within the Huachuca and Santa Rita mountain foothills in southeastern Arizona. We used pointing dogs to locate quail during the pairing seasons of 1998 and 1999, and measured habitat characteristics at 60 flush sites and 60 associated random plots (within $100 \mathrm{~m}$ of flush sites). We recorded information on landform, substrate, vegetation, and cover. Montezuma quail selected $(P<0.10)$ areas with higher grass canopy cover and more trees than randomly available. Short $(\leq 50 \mathrm{~cm}$ tall) visual obstruction (cover), usually associated with bunch grass, was greater $(P<0.10)$ at use sites than at random plots. Land management practices that reduce grass and tree cover may affect Montezuma quail habitat quality and availability in southeastern Arizona. Based on habitat selection patterns of Montezuma quail, we recommend that oak woodland habitats should contain a minimum tree canopy of $26 \%$, and $51-75 \%$ grass canopy cover at the $20-\mathrm{cm}$ height to provide optimum cover availability.

Key Words: Arizona; Cyrtonyx montezumae, grazing, habitat selection, livestock, Madrean evergreen woodland, Montezuma quail

Several authors have described general habitat associations of Montezuma quail (Cyrtonyx montezumae Vigors) (Wallmo 1954, Leopold and McCabe 1957, Bishop 1964, Brown 1978). Montezuma quail inhabit Madrean evergreen woodlands of southwestern United States and Mexico, and are usually found in close association with oak (Quercus spp.) overstory (Leopold and McCabe 1957, Marshall 1957). Montezuma quail are dependent upon perennial bunch grasses for escape and thermal cover, and for nest construction (Wallmo 1954, Leopold and McCabe 1957, Bishop 1964, Brown 1978). Montezuma quail feed on subter-

Funding for this study was provided by the Federal Aid in Wildlife Restoration Act through Project W-78-R of the Arizona Game and Fish Department. Authors wish to thank Mike Rabe for assistance in statistical analysis. Jim deVos, Jim Heffelfinger, Ron Olding and Brian Wakeling provided valuable editorial comments that improved the final version of the manuscript.

Manuscript accepted 4 Mar. 04.

\section{Resumen}

La cordoníz Montezuma (Cyrtonyx montezumae Vigors) está estrechamente asociada con los bosques de robles (Quercus $\mathrm{spp}$.). Se considera que el pastoreo de ganado y el acceso a la cobertura son factores importantes que afectan la distribución y densidad de la cordoníz Montezuma. Mientras que, para la supervivencia y reproducción de la cordoníz Montezuma, se consideran importantes las condiciones de hábitat durante la temporada de apareamiento (Abril-Junio), la información acerca de la selección de habitat durante esa temporada es limitada. Instrumentamos una investigación sobre selección de habitat por la codorníz Montezuma en sitios de pastoreo y de no pastoreo en las faldas majas de las montanas Huachuca y Santa Rita en el sureste de Arizona. Durante la temporada de de apareamiento en 1998 y 1999 empleamos perros de caza para localizar las cordoníces y medimos características de hábitat en 60 sitios de despegue y otros 60 sitios al azar (dentro de $100 \mathrm{~m}$ de sitios de despegue). Recabamos información acerca del paisaje, substrato, vegetación y de cobertura. La cordoníz Montezuma seleccionó $(\mathbf{P}<0.10)$ sitios con cobertura de pasto más alto y más arbolado que los que existen al azar. Baja altura $(\leq \mathbf{5 0} \mathrm{cm}$ de altura) de obstrucción visual (cobertura), ordinariamente asociada con pastizales, resultó mayor $(P<0.10)$ en sitios de uso que en sitios al azar. Las prácticas de manejo de suelos que reducen los pastizales y la cobertura de arboles pueden afectar la calidad del habitat y la disponibilidad del hábitat para la cordoníz Montezuma en el sureste de Arizona. En base a patrones de selección de hábitat de la codorníz Montezuma, recomendamos que los hábitats de bosques de roble deben contener un mínimo the cobertura de árboles de $26 \%$, y $51-75 \%$ de cobertura de pasto a $20-\mathrm{cm}$ de altura para ofrecer disponibilidad de cobertura óptima.

ranean bulbs and tubers of several forb species (Bishop and Hungerford 1965). These forbs, as well as most perennial bunch grasses in this area, are dependent upon summer precipitation. Brown (1979) showed a positive correlation between summer rainfall and Montezuma quail harvest suggesting a link to reproductive success and survival. Montezuma quail begin to pair as early as late February, but breeding is usually delayed until late June (Bishop 1964).

Overgrazing by livestock is considered an important factor affecting distribution and abundance of Montezuma quail (Leopold and McCabe 1957, Bishop 1964, Brown 1978, 1982). Brown (1982) reported that while livestock grazing can increase availability of plants consumed by Montezuma quail, areas that had reduced grass cover because of excessive grazing were devoid of Montezuma quail. In ungrazed habitats, Stromberg 
(1990) found that Montezuma quail selected areas with tall bunch grasses on northfacing hillsides for day use and roosted on southeast-facing slopes. Since perennial bunch grasses that Montezuma quail use for cover are warm-season species (Bishop 1964), hiding cover is most limited during the spring and early summer pairing season (Brown 1982). Brown (1982) considered the amount of "residual grass cover" available during spring to be the most important factor affecting Montezuma quail survival and reproduction in grazed areas.

Although general habitat affinities of Montezuma quail have been described (Wallmo 1954, Leopold and McCabe 1957, Bishop 1964) only Albers and Gelbach (1990) and Stromberg (1990) attempted to relate habitat characteristics used to the range of available habitat conditions. While other studies suggested that pairing season habitat conditions may affect annual survival and reproduction (Bishop 1964, Brown 1978, Brown 1979), no attempt has been made to quantify Montezuma quail habitat use during pairing season. In this study, we quantified habitat selection by Montezuma quail during the pairing season within Madrean evergreen woodland-grassland habitat of southeastern Arizona.

\section{Materials and Methods}

\section{Study Area}

We conducted our study in the foothills of the Santa Rita and Huachuca Mountains in Santa Cruz County, southeastern Arizona. The area is composed primarily of Madrean evergreen woodlands interspersed with semi-desert grasslands (Brown 1994a). Various live oaks dominated the vegetation, including Mexican blue oak ( $Q$. oblongifolia Torr.), Emory oak (Q. emoryi Torr.), and Arizona white oak (Q. arizonica Sarg.) (Brown 1994a). Alligator juniper (Juniperus deppeana Steud.) mimosa (Mimosa L. spp.), manzanita (Arctostaphylos Adans. spp.), and mesquite (Prosopis juliflora Swartz) were found in more xeric locations (Brown 1994a). Trees and shrubs dominated north-facing slopes, whereas perennial bunch grasses (Aristida L. spp., Bouteloua Lag. spp., Eragrostis Wolf spp., and Trichachne Nees spp.) dominated southfacing slopes and tops of ridges (Brown 1994b). Riparian areas contained mixtures of cottonwood (Populus fremontii Wats.), willow (Salix L. spp.), and sycamore (Platanus wrightii Wats.) (Minckley and Brown 1994). We concentrated our efforts within Madrean evergreen woodlands, the vegetation type most often associated with Montezuma quail (Brown 1982). Topography consisted of rolling hills broken by numerous small canyons; elevation ranged between 1,200-1,500 m. Annual precipitation averaged $35.7 \mathrm{~cm}$ at Canelo, Ariz. and was lower than the long-term average of $45.8 \mathrm{~cm}$. Precipitation was bimodally distributed with peaks in winter and late summer (Natl. Oceanic and Atmos. Adm. 1998, 1999).

We collected data in 2 study sites to assess habitat selection of Montezuma quail under different land-use regimes. The Research Ranch, managed by the National Audubon Society in cooperation with the U. S. Bureau of Land Management and U. S. Forest Service (USFS), has been protected from grazing and tree removal since $1968\left(31^{\circ} 35^{\prime} \mathrm{N} 110^{\circ} 34^{\prime} \mathrm{W}\right.$, Fig. 1). Removal of grazing at the Research Ranch in 1968 has increased vegetative diversity and coverage, and changed plant species composition, such that taller grasses (Bouteloua Lag. spp., and Eragrostis Wolf spp.) have become more predominant (Brady et al. 1989). The USFS Coronado National Forest managed the grazed study site in the foothills of the Santa Rita Mountains $\left(31^{\circ} 40^{\prime} \mathrm{N} 110^{\circ} 42^{\prime} \mathrm{W}\right.$, Fig. 2). Montezuma quail hunting was allowed on Coronado National Forest but not the

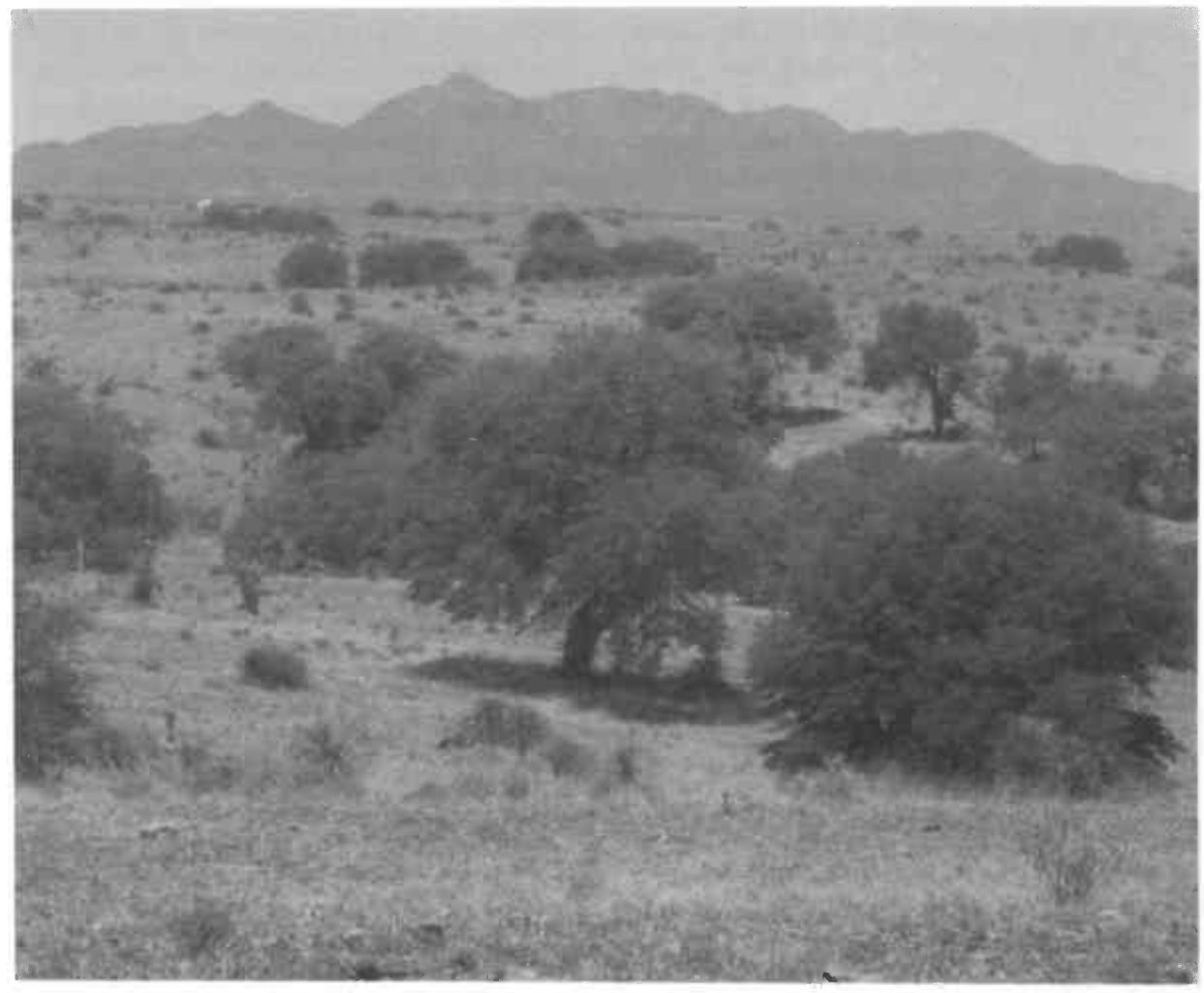

Fig. 1. Typical Montezuma quail habitat at the National Audubon Society Research Ranch study area subunit in the foothills of the Huachuca Mountains, southeastern Arizona. 


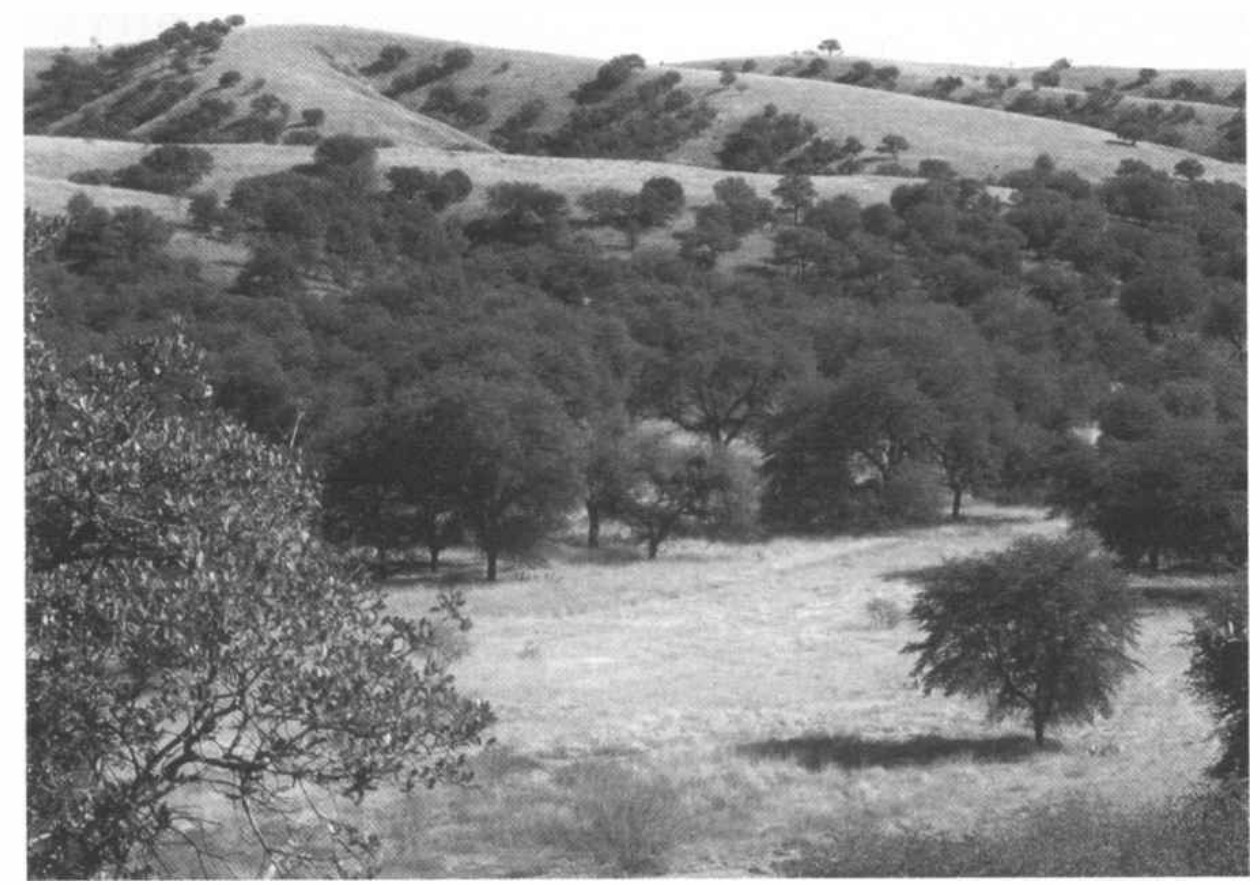

Fig. 2. Typical Montezuma quail habitat at the Coronado National Forest study area subunit in the foothills of the Santa Rita Mountains, southeastern Arizona.

component measurements at the approximate center of a flush site or feeding sign (small excavations made by Montezuma quail). We recorded the covey behavior at each flush site. Montezuma quail tend to hold very tight and seldom run before flushing, therefore, flush sights were likely representative of feeding and loafing habitats. We recorded date, time of day, study site, and used a Global Positioning System unit to obtain Universal Transverse Mercator coordinates for each site.

Previous authors suggested that slope aspect, terrain, and soil type affects habitat selection of Montezuma quail (Brown 1978, Holdermann and Holdermann. 1997). Therefore we described landform and substrate of flush sites by measuring soil compaction and slope aspect, and by classifying terrain type. We measured soil compaction $\left(\mathrm{kg} / \mathrm{cm}^{2}\right)$ with a penetrometer at 1-m intervals along 2 perpendicular, 6$m$ transects that intersected at their midpoints on the site center. We averaged the 12 readings to obtain an estimate of soil compaction at the site. We measured slope aspect with a compass and assigned each site an aspect category, of north $\left(316-359^{\circ}\right.$ and $\left.0-45^{\circ}\right)$, east $\left(46-135^{\circ}\right)$, south $\left(136-225^{\circ}\right)$, and west $\left(226-315^{\circ}\right)$. We also assigned each site a terrain category based on position on the slope. Terrain categories were: ridge top, upper half of ridge, lower half of ridge, or drainage bottom. measurements oriented along transect lines, then averaged values for each height class. We recorded the maximum height of $50 \%$ obstruction as the uppermost height category at which the average number of visible intersections was $\leq 5.0$ (i.e., visual obstruction $\geq 50 \%$ ).

We measured the same habitat variables in the same manner at flush sites and an equal number of associated $(<100 \mathrm{~m}$ from flush sites) random plots. We located random plots by travelling a random number of paces $(0-100)$, in a random direction $\left(0-360^{\circ}\right)$, from each flush site. We used a random number table to determine direction and number of paces (Zar 1984). Transect lines at plots were oriented in the same random direction as the associated flush site.

\section{Statistical Analyses}

Using data collected at the Research Ranch (ungrazed), we compared habitat measurements from quail flush sites with habitat measurements collected at associated random plots to determine which factors influenced habitat selection. To detect differences in availability of habitat components between study sites we compared random plot habitat measurements between study area subunits. To determine if the grazing program administered by the USFS on Coronado National Forest (grazed) impacted Montezuma quail habitat use, we compared flush site habitat measurements between study area subunits. To describe habitat preferences of Montezuma quail over a range of habitats, we pooled data collected on important habitat variables from both study area subunits.

We realized that we performed multiple tests of variables with a potential lack of independence, and the experimentwise error rate could have been high. However, because this study was designed to provide improved guidelines for habitat management of Montezuma quail, and relatively little is known about their habitat selection patterns, we accepted Type I errors as preferable to Type II errors. Therefore, in order to minimize the potential for Type II errors, we chose not to apply Bonferroni corrections to $\alpha$ levels. We considered differences to be statistically significant if $\mathrm{P} \leq 0.10$.

We used 2 sample t-tests for all continuous data sets (Zar 1984). For categorical data, we calculated Bonferroni confidence intervals for habitat parameters at flush sites (Neu et al. 1974, Byers et al. 1984). If availability, as determined from random plots, differed from use, we calculated a Jacobs' D selectivity index (Jacobs 1974) to determine magnitude of selection (1.0 to -1.0$)$. 


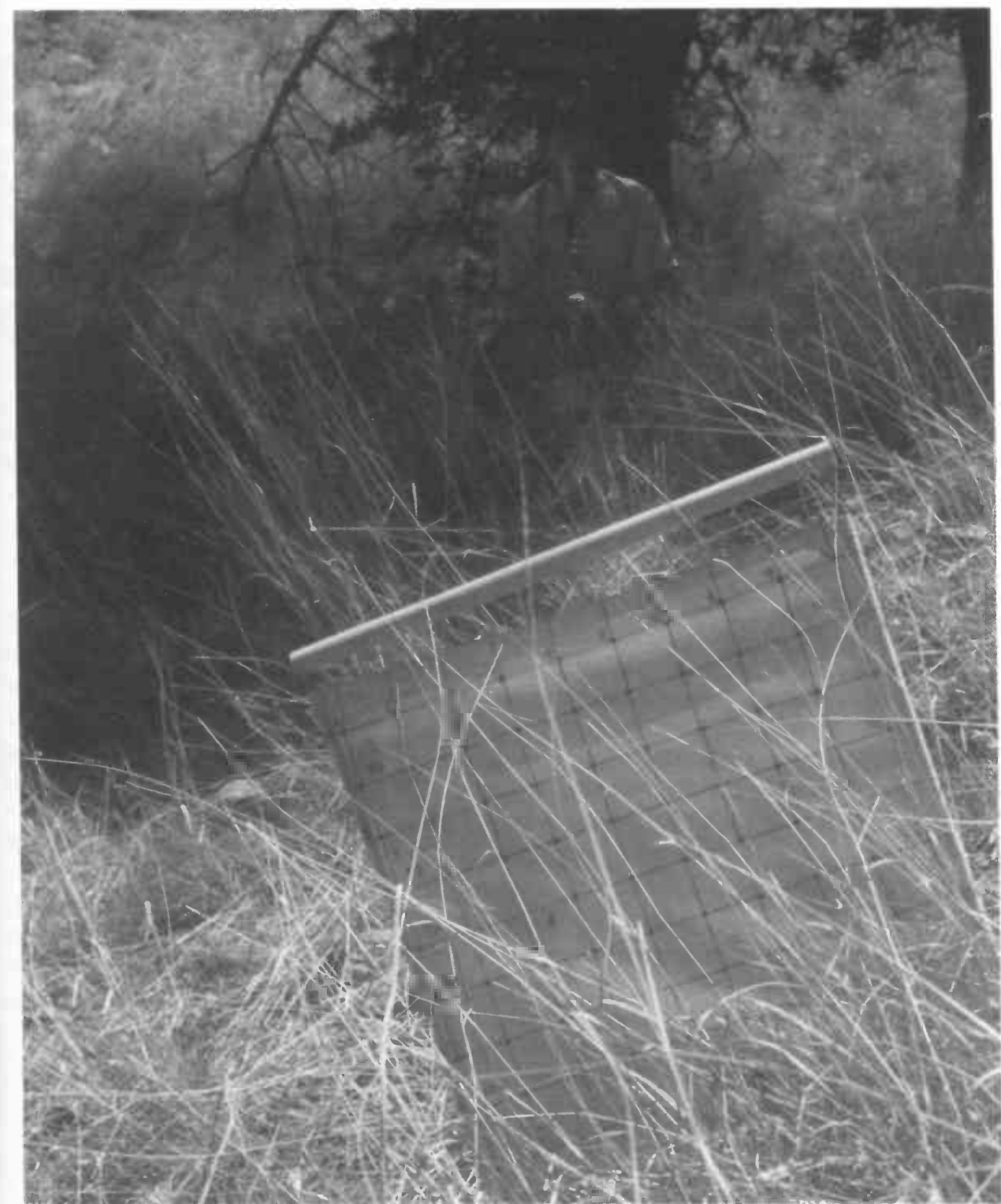

Fig. 3. Visibility board used to measure vertical structure around flush sites. We recorded number of intersections (1-10) visible at each of the 10 levels.

\section{Results}

We located 60 coveys of Montezuma quail (Coronado National Forest $\mathrm{n}=30$ and the Research Ranch $\mathrm{n}=30$ ) during the pairing seasons of $1998(\mathrm{n}=30)$, and 1999 $(n=30)$. Based on the distribution of flush sites and pairing season use area sizes (1.69 - $6.67 \mathrm{ha})$ of Montezuma quail calculated by Stromberg (1990), we were confident that we sampled $\geq 23$ independent pairs each year. Most ( $\geq 23$ each year) flush sites were $\geq 1 \mathrm{~km}$ from the next nearest flush site. We found 33\% of the coveys in April, 52\% in May, and 15\% in June. Locating pairs in June using pointing dogs was difficult because of high temperatures. In both study area subunits we found most coveys $(82 \%)$ in the morning and early afternoon $(\leq 1400$ Hours MST), as increasing temperatures to continue hunting for Montezuma quail.

${ }^{1}$ Differences determined by 2 sample t-tests.

${ }^{2}$ Average maximum height at which the visual obstruction $\geq 50 \%$
We flushed a total of 133 birds and were able to classify $94 \%$ of birds encountered as male or female. Average covey size was 2.4 at the Research Ranch, and 2.0 at Coronado National Forest, and $60 \%$ of the coveys were male-female pairs. We were able to classify the activity of $83 \%$ of "coveys" found. We classified $75 \%$ of the coveys as feeding, $2 \%$ roosting, and $6 \%$ travelling.

\section{Habitat measurements}

At the Research Ranch, soil compaction of Montezuma quail flush sites was not different from random plots (Table 1). Montezuma quail at the Research Ranch selected east-facing slopes (Table 2), and used other aspect categories according to availability. At the Research Ranch, Montezuma quail selected the upper half of ridges, avoided ridge tops, and used other terrain categories according to availability (Table 3 ).

\section{Vegetation Sampling}

At the Research Ranch, species richness was greater at flush sites for trees than at random plots (Table 1). Species richness for grasses, forbs and shrubs did not differ between flush sites and random plots (Table 1). Distances to nearest shrub did not differ between flush sites and random plots (Table 1). Flush sites were closer to trees than were centers of random plots, and DBH of the closest trees were greater at flush sites than at random plots (Table 1). Flush sites had greater levels of grass and tree canopy than did random plots (Table 1). Forb and shrub canopy cover did not differ between flush sites and random plots (Table 1).

Random plots at Coronado National Forest (grazed) had greater tree canopy,

Table 1. Means $( \pm$ SD) of habitat variables at Montezuma quail flush sites $(n=30)$ and associated random plots $(n=30)$ at the National Audubon Society Research Ranch in the Huachuca Mountains, southeastern Arizona, April-June 1998 and 1999.

\begin{tabular}{lccc}
\hline \hline Variable & Flush & Random & P1 \\
\hline Soil compaction $\left(\mathrm{kg} / \mathrm{cm}^{2}\right)$ & $1.0 \pm 1.2$ & $1.4 \pm 0.9$ & 0.214 \\
Grass species richness & $4.9 \pm 1.7$ & $4.3 \pm 1.5$ & 0.150 \\
Forb species richness & $6.2 \pm 3.2$ & $5.2 \pm 3.2$ & 0.258 \\
Tree species richness & $0.8 \pm 0.7$ & $0.3 \pm 0.5$ & 0.002 \\
Shrub species richness & $1.4 \pm 1.4$ & $1.6 \pm 1.3$ & 0.439 \\
Distance to nearest tree (m) & $7.4 \pm 6.7$ & $16.3 \pm 11.1$ & $<0.001$ \\
DBH of nearest tree $(\mathrm{cm})$ & $34.0 \pm 26.8$ & $19.8 \pm 17.9$ & 0.019 \\
Distance to nearest shrub $(\mathrm{m})$ & $9.6 \pm 10.7$ & $5.7 \pm 7.3$ & 0.109 \\
Grass canopy cover $(\%)$ & $58.7 \pm 15.1$ & $50.6 \pm 15.4$ & 0.045 \\
Forb canopy cover $(\%)$ & $7.8 \pm 6.2$ & $10.6 \pm 9.9$ & 0.182 \\
Tree canopy cover $(\%)$ & $25.3 \pm 16.6$ & $13.2 \pm 15.9$ & 0.006 \\
Shrub canopy cover $(\%)$ & $5.6 \pm 5.2$ & $7.1 \pm 8.3$ & 0.394 \\
Maximum 50\% obstruction $(\mathrm{cm})^{2}$ & $18.5 \pm 16.5$ & $7.2 \pm 4.5$ & 0.001 \\
\hline
\end{tabular}


Table 2. Use of aspect of slope class at Montezuma quail flush sites $(n=30)$ compared to associated random plots $(n=30)$ at the National Audubon Society Research Ranch in the Huachuca Mountains, southeastern Arizona, April - June 1998 and 1999.

\begin{tabular}{lcccc}
\hline \hline Aspect & $\begin{array}{c}\text { No. of } \\
\text { Locations } \\
\text { observed }\end{array}$ & $\begin{array}{c}\text { No. of } \\
\text { locations } \\
\text { expected }\end{array}$ & $\begin{array}{c}\text { Bonferronio } \\
90 \% \text { CI }\end{array}$ & $\begin{array}{c}\text { Jacobs' } \\
D 1\end{array}$ \\
\hline North & 18 & 19 & $13.8-22.3$ & 0.76 \\
East & 6 & 1 & $2.5-9.5$ & \\
South & 3 & 5 & $0.4-5.6$ & \\
West & 3 & 5 & $0.4-5.6$ & \\
\hline
\end{tabular}

'Jacobs' $D$ represents magnitude of selection or avoidance, from 1.0 to -1.0 .

Table 3. Use of terrain class at Montezuma quail flush sites $(n=30)$ compared to associated random plots $(n=30)$ at the National Audubon Society Research Ranch in the Huachuca Mountains, southeastern Arizona, April - June 1998 and 1999.

\begin{tabular}{lcccc}
\hline \hline Terrain class & $\begin{array}{c}\text { No. of } \\
\text { Locations } \\
\text { observed }\end{array}$ & $\begin{array}{c}\text { No. of } \\
\text { locations } \\
\text { expected }\end{array}$ & $\begin{array}{c}\text { Bonferronio } \\
90 \% \text { CI }\end{array}$ & $\begin{array}{c}\text { Jacobs' } \\
D 1\end{array}$ \\
\hline Drainage bottom & 11 & 13 & $6.8-15.2$ & \\
Lower 1/2 of ridge & 5 & 5 & $1.8-8.3$ & \\
Upper 1/2 of ridge & 13 & 8 & $8.7-17.3$ & 0.35 \\
Top of ridge & 1 & 4 & $0.0-2.5$ & -0.63 \\
\hline
\end{tabular}

'Jacobs' $D$ represents magnitude of selection or avoidance, from 1.0 to -1.0 .

Table 4. Means ( \pm SD) of important habitat variables at random plots collected at the National Audubon Society Research Ranch (TRR, $n=30$ ) and Coronado National Forest $(C N F, n=30)$ study area subunits in the Huachuca and Santa Rita mountains, southeastern Arizona, April-June 1998 and 1999.

\begin{tabular}{lccr}
\hline \hline Variable & TRR & CNF & \multicolumn{1}{c}{$\mathrm{P}^{1}$} \\
\hline Tree species richness & $1.6 \pm 1.1$ & $2.0 \pm 1.8$ & 0.268 \\
Distance to nearest tree $(\mathrm{m})$ & $16.3 \pm 11.1$ & $6.3 \pm 5.5$ & $<0.001$ \\
DBH of nearest tree $(\mathrm{cm})$ & $19.8 \pm 17.9$ & $25.1 \pm 33.7$ & 0.448 \\
Grass canopy cover $(\%)$ & $50.6 \pm 15.4$ & $41.2 \pm 20.9$ & 0.054 \\
Tree canopy cover $(\%)$ & $13.2 \pm 15.9$ & $38.3 \pm 24.5$ & $<0.001$ \\
Maximum 50\% obstruction $(\mathrm{cm}) 2$ & $19.8 \pm 17.9$ & $25.1 \pm 33.7$ & 0.259 \\
\hline
\end{tabular}

Differences determined by 2 sample t-tests.

${ }^{2}$ Average maximum height at which the visual obstruction $\geq 50 \%$.

Table 5. Means $( \pm \mathrm{SD}$ ) of important habitat variables at Montezuma quail flush sites collected at the National Audubon Society Research Ranch (TRR, $n=30$ ) and Coronado National Forest $(\mathrm{CNF}, \mathrm{n}=30)$ study area subunits in the Huachuca and Santa Rita mountains, southeastern Arizona, April - June 1998 and 1999.

\begin{tabular}{lccc}
\hline \hline Variable & TRR & CNF & $\mathrm{P}^{1}$ \\
\hline Tree species richness & $0.8 \pm 0.7$ & $1.3 \pm 0.7$ & 0.011 \\
Distance to nearest tree $(\mathrm{m})$ & $7.4 \pm 6.7$ & $3.8 \pm 2.3$ & 0.008 \\
DBH of nearest tree $(\mathrm{cm})$ & $34.0 \pm 26.8$ & $27.8 \pm 17.8$ & 0.299 \\
Grass canopy cover $(\%)$ & $58.7 \pm 15.1$ & $48.3 \pm 13.7$ & 0.007 \\
Tree canopy cover $(\%)$ & $25.3 \pm 16.6$ & $42.8 \pm 17.2$ & $<0.001$ \\
Maximum 50\% obstruction $(\mathrm{cm})^{2}$ & $18.5 \pm 16.5$ & $13.3 \pm 13.7$ & 0.192 \\
\hline
\end{tabular}

Differences determined by 2 sample t-tests.

Table 6. Use of percent grass canopy cover class at Montezuma quail flush sites $(n=60)$ compared to associated random plots $(n=60)$ at the National Audubon Society Research Ranch and Coronado National Forest study area subunits in the Huachuca and Santa Rita mountains, southeastern Arizona, April - June 1998 and 1999.

\begin{tabular}{lcccc}
\hline \hline $\begin{array}{l}\text { Grass } \\
\text { canopy } \\
\text { cover }\end{array}$ & $\begin{array}{c}\text { No. of } \\
\text { Locations } \\
\text { observed }\end{array}$ & $\begin{array}{c}\text { No. of } \\
\text { locations } \\
\text { expected }\end{array}$ & $\begin{array}{c}\text { Bonferronio } \\
90 \% \text { CI }\end{array}$ & $\begin{array}{c}\text { Jacobs' } \\
D 1\end{array}$ \\
\hline $0-25 \%$ & 1 & 8 & $0.0-2.6$ & -0.80 \\
$26-50 \%$ & 22 & 26 & $16.1-27.9$ & \\
$51-75 \%$ & 34 & 23 & $27.9-40.0$ & 0.36 \\
$76-100 \%$ & 3 & 3 & $0.0-5.7$ & \\
\hline
\end{tabular}

'Jacobs' $D$ represents magnitude of selection or avoidance, from 1.0 to -1.0 . lower levels of grass canopy, and were closer to the nearest tree than random plots at the Research Ranch (Table 4). Similarly, flush sites at Coronado National Forest had higher tree species richness and tree canopy, lower levels of grass canopy, and were closer to the nearest tree than flush sites at the Research Ranch (Table 5). At both study area subunits Montezuma quail avoided areas that had $\leq 25 \%$ grass canopy cover ( $>10 \mathrm{~cm}$ high) and selected areas that had $51-75 \%$ grass canopy cover (Table 6). Montezuma quail also avoided areas that had $\leq 25 \%$ tree canopy cover and selected areas that had $26-50 \%$ tree canopy cover (Table 7).

Both methods we used to measure visual obstruction indicated that Montezuma quail used areas with more cover than found at random plots. At the Research Ranch, visual obstruction was greater at flush sites for all 10 height levels of the visibility board than that seen at random plots ( $\mathrm{P} \leq 0.001$, Fig. 4). At Coronado National Forest, visual obstruction was greater at flush sites for all height levels $\leq$ $25 \mathrm{~cm}$ of the visibility board than that seen at random plots $(\mathrm{P} \leq 0.001$, Fig. 4$)$. At the Research Ranch, mean maximum height of $50 \%$ obstruction was higher at flush sites than at random plots (Table 1), but was not different from flush sites at Coronado National Forest (Table 5).

\section{Discussion and Conclusions}

We found that within Madrean evergreen woodland, characteristics such as landform, vegetative richness, and cover affect pairing season habitat selection of Montezuma quail. Flush site characteristics were different from random plots for the majority $(67 \%)$ of the habitat variables we measured. Our findings are similar to earlier descriptions of habitats used by Montezuma quail (Bishop 1964, Brown 1982, Stromberg 1990, Bristow and Ockenfels 2002). We found that Montezuma quail used forested areas with higher vegetative diversity and greater amounts of cover than randomly available. These habitat components can be affected by current land uses on the Coronado National Forest.

\section{Effects of tree removal}

Most accounts of Montezuma quail consider oak trees to be an important habitat component (Miller 1943, Wallmo 1954, Leopold and McCabe 1957, Brown 1982). We found that Montezuma quail selected areas near larger trees, with greater canopy cover and tree species richness. Bishop and 


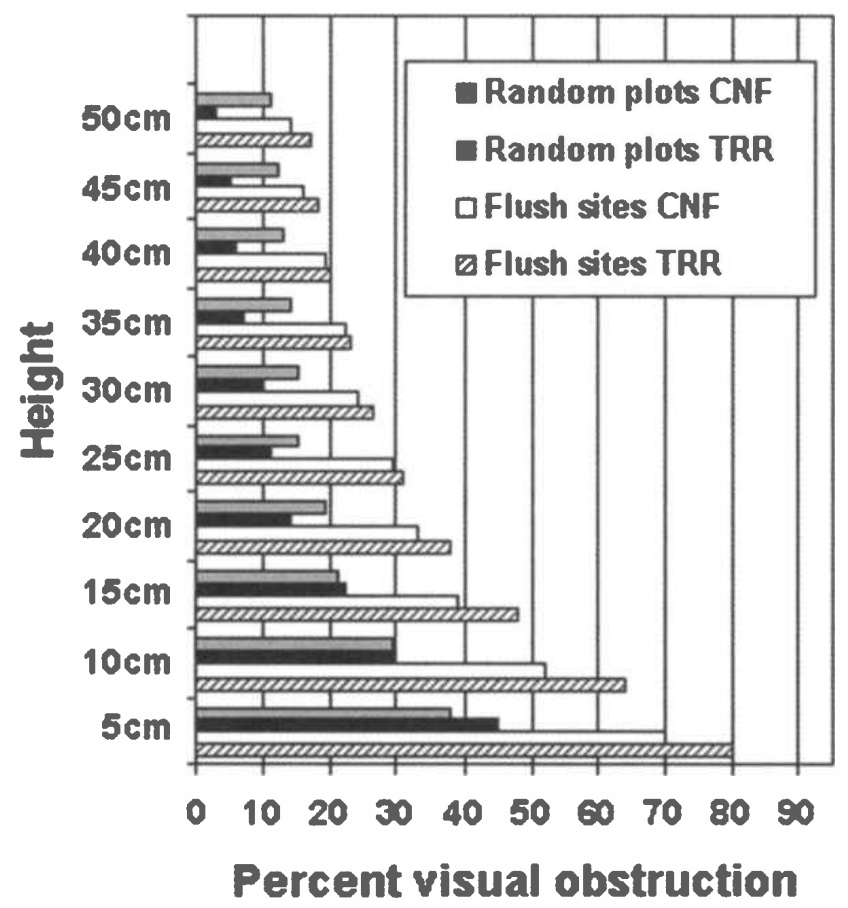

Fig. 4. Average visual obstruction by height class taken at Montezuma quail flush sites at the National Audubon Society Research Ranch $(T R R, n=30)$ and the Coronado National Forest $(C N F, n=30)$ study area subunits, compared to associated random plots $(n=60)$, in the Huachuca and Santa Rita mountains, southeastern Arizona, April-June 1998 and 1999. Differences significant $(P \leq 0.10)$ according to 2 sample $t$-tests, (TRR $=$ all height levels, CNF = all height levels $\leq 25 \mathrm{~cm}$ ).

Hungerford (1965) found that mast from various species of oaks was important in Montezuma quail diets only during the autumn. Therefore the use of areas near larger trees by Montezuma quail that we documented is probably not related to mast availability. Selection for east-facing slopes near ridge tops likely was related to the proximity to trees, as these sites had denser tree canopies at the Research Ranch. Temperature can affect habitat selection and behavior of quail (Goldstein 1984) and Bishop (1964) found Montezuma quail used mesquite grassland areas with dense mesquite trees and no oak trees. Montezuma quail probably select areas near trees for thermal and hiding cover and presence of food resources.

Given the importance of tree canopy cover, tree removal for timber or fuelwood could substantially impact Montezuma quail habitat. Brown (1982) suggested that tree canopy $>30 \%$ was optimal for Montezuma quail habitat. Our data show that Montezuma quail selected for areas with $26-50 \%$ tree canopy cover and used areas with $\geq 50 \%$ tree canopy cover according to availability. We suggest that tree canopy of $\geq 26 \%$ be maintained in Madrean evergreen woodlands to provide the optimum microclimate for Montezuma quail.

\section{Effects of livestock grazing}

Much of the habitat selection of Montezuma quail can be explained by their specific dietary requirements (Bishop 1964). Underground bulbs and tubers of yellow nutsedge (Cyperus esculentes) and Gray's woodsorrel (Oxalis grayi) comprise a substantial portion of Montezuma quail diets (Bishop and Hungerford 1965). Holdermann and Holdermann (1997) found that Montezuma quail in New Mexico were associated with yellow nutsedge and Gray's woodsorrel. Bristow and Ockenfels (2002) considered selection of areas with higher forb species richness by Montezuma Quail in the brood season to be diet-related. We found no difference in forb species richness between flush sites and random plots. However, yellow nutsedge and Gray's woodsorrel are sumsoutheastern Arizona, April - June 1998 and 1999. mer growing species and above ground portions were not present during our spring measurements. Most of our locations $(75 \%)$ were feeding sites that contained evidence of digging. Thus, it is likely that Montezuma quail are selecting areas for food availability.

Brown (1982) found that grazed areas in Madrean evergreen woodland had more quail foods than ungrazed areas. This implies that if cover requirements are met, moderate livestock grazing may actually improve habitat conditions for Montezuma quail. The most marked difference between flush sites and random plots was in the amount of visual obstruction and cover. Flush sites had higher percent canopy cover from grass and trees, and higher visual obstruction. Visual obstruction readings at all levels of the visibility board were higher at flush sites in ungrazed areas, as was percent grass canopy. Obviously, grass cover is important to Montezuma quail. However grazing affects cover availability inconsistently across an area, as grazing ungulates are selective in their feeding (Abdullahi 1980). Perennial bunch grasses, which make up the majority of escape cover, typically occur in a patchy distribution, and moderate livestock grazing may further promote patchiness (Abdullahi 1980).

While our study area encompassed both grazed and ungrazed areas, amount of visual obstruction at flush sites was consistent between grazed and ungrazed areas. Thus, Montezuma quail were still able to find suitable cover in areas with moderate grazing pressure $(<45 \%$ utilization); however, birds selected areas with less cover removed by livestock. Differences between flush sites in grazed and ungrazed areas were likely because of availability of specific habitat components; the Research Ranch contained fewer trees and had greater grass canopy than Coronado National Forest.

Northern bobwhite quail (Colinus virginianus L.) use areas with greater vertical structure as loafing habitat, primarily for

Table 7. Use of percent tree canopy cover class at Montezuma quail flush sites $(n=60)$ compared to associated random plots $(n=60)$ at the National Audubon Society Research Ranch and Coronado National Forest study area subunits in the Huachuca and Santa Rita mountains,

\begin{tabular}{lcccc}
\hline \hline $\begin{array}{l}\text { Tree } \\
\text { canopy } \\
\text { cover }\end{array}$ & $\begin{array}{c}\text { No. of } \\
\text { Locations } \\
\text { observed }\end{array}$ & $\begin{array}{c}\text { No. of } \\
\text { locations } \\
\text { expected }\end{array}$ & $\begin{array}{c}\text { Bonferronio } \\
90 \% \text { CI }\end{array}$ & $\begin{array}{c}\text { Jacobs' } \\
\text { 1 }\end{array}$ \\
\hline $0-25 \%$ & 22 & 36 & $16.1-27.9$ & -0.44 \\
$26-50 \%$ & 26 & 11 & $19.9-32.1$ & 0.55 \\
$51-75 \%$ & 11 & 11 & $6.2-15.7$ & \\
$76-100 \%$ & 1 & 2 & $0.0-2.6$ & \\
\hline
\end{tabular}

'Jacobs' $D$ represents magnitude of selection or avoidance, from 1.0 to -1.0 . 
thermal cover (Johnson and Guthery 1988). King (1998) found a similar relationship for masked bobwhite $(C$. $v$. ridgwayi Ridgway) in southern Arizona grasslands. Stormer (1984) found that scaled quail (Callipepla squamata Vigors) roosted in areas with greater amounts of cover and considered it a predator avoidance strategy. The primary predator avoidance strategy of Montezuma quail is to remain motionless, relying on cryptic coloration to avoid detection (Leopold and McCabe 1957). This behavior is only effective when there is sufficient cover to hide birds. Based on the average maximum height of $50 \%$ visual obstruction at flush sites, and the obstruction levels selected at Coronado National Forest, we believe a minimum grass height of $20 \mathrm{~cm}$ is adequate vertical cover to protect Montezuma quail from ground predators. However, predation from raptors is the greatest source of natural mortality for Montezuma quail (Bishop 1964, Stromberg 1990), and our visibility board data suggest that higher visual obstruction (up to $50 \mathrm{~cm}$ ) could be important to decrease risk of detection by aerial predators.

Brown (1982) found that Montezuma quail were absent from otherwise suitable habitat where available grass cover had been reduced at levels $>55 \%$ of standing annual biomass. Brown (1982) recommended that livestock use rates be maintained at $\leq 40 \%$ of annual standing biomass to maintain Montezuma quail in an area. These recommendations can be misleading because amount of cover remaining varies with annual production. Cover requirements of Montezuma quail are likely consistent regardless of annual production, thus in years of lower production, utilization may need to be decreased to ensure that cover requirements are met.

Montezuma quail selected areas that had $51-75 \%$ grass canopy cover $(>10 \mathrm{~cm}$ high), and the mean grass canopy cover ( $>10 \mathrm{~cm}$ high) at flush sites was $59 \%$. We recommend that oak woodland habitats should contain $51-75 \%$ grass canopy cover at the $20-\mathrm{cm}$ height, to ensure optimum cover availability for Montezuma quail. Areas with greater grass canopy cover would likely contain more suitable habitat, provided that food resources were present. We did not look at relative densities or productivity of populations in different habitats, however there likely is a relationship between habitat quality and population viability. Future research should focus on relative bird densities and nesting success under different habitat conditions, especially with respect to the spatial and temporal availability of cover and specific food resources.

\section{Literature Cited}

Abdullahi, A.N. 1980. Forage preference of cattle and land in a desert grassland in southern Arizona. Ph.D. Diss. Univ. Arizona, Tucson, Ariz.

Albers, R.P. and F.R. Gehlbach. 1990. Choices of feeding habitat by relict Montezuma quail in central Texas. Wilson Bull. 102:300-308.

Bishop, R.A. 1964. The Mearns quail (Cyrtonyx montezumae mearnsi) in southern Arizona. M.S. Thesis. Univ. Arizona, Tucson, Ariz.

Bishop, R.A. and C.R. Hungerford. 1965. Seasonal food selection of Arizona Mearns Quail. J. Wildl. Manage.29:813-819.

Brady, W.W., M.R. Stromberg, E.F. Aldon, C.D. Bonham, and S.H. Henry. 1989. Response of a semidesert grassland to 16 years of rest from grazing. J. Range Manage. 42:284-288.

Bristow, K.D. and R.A. Ockenfels. 2002. Brood season habitat selection by Montezuma quail in southeastern Arizona. Proc. of the Nat. Quail Symp. 5:111-116.

Brown, D.E. 1979. Factors influencing the reproductive success and population densities in Montezuma quail. J. Wildl. Manage. 43:522-526.

Brown, D.E. 1994a. Warm-temperate forests and woodlands. p. 58-78. In: D.E. Brown, (ed.) Biotic communities: southwestern United States and northwestern Mexico. Univ. Utah Press, Salt Lake City, Ut.

Brown, D.E. 1994b. Grasslands. p. 107-142. In: D.E. Brown, (ed.) Biotic communities: southwestern United States and northwestern Mexico. Univ. Utah Press, Salt Lake City,Ut.

Brown, R.L. 1978. An ecological study of Mearns' quail. Arizona Game and Fish Department Federal Aid in Wildlife Restoration final report, Project W-78-R-22, Phoenix. Ariz.

Brown, R.L. 1982. Effects of livestock grazing on Mearns quail in southeastern Arizona. J. Range Manage. 35:727-732.

Byers, C.R., R.K. Steinhorst, and P.R. Krausman. 1984. Clarification of a technique for analysis of utilization-availability data. J. Wildl. Manage. 48:1050-1053.

Goldstein, D.L. 1984. The thermal environment and its constraint on activity of desert quail in summer. Auk 101:542-550.

Holdermann, D. and R. Holdermann. 1997. Distribution, phenology, ecological relationships, and below ground biomass of Cyperus esculentus and Oxalis grayi in relation to Montezuma quail at the Fort Stanton Special Management area. New Mexico Dep. of Game and Fish Res. Rep. \#95-516-49, Santa Fe, N.M.

Jacobs, J. 1974. Quantitative measurements of food selection. Oecologia 14:413-417.

Johnson, D.B. and F.S. Guthery. 1988. Loafing coverts used by northern bobwhites in subtropical environments. J. Wildl. Manage. 52:464-469.
King, N.M. 1998. Habitat use by endangered masked bobwhites and other quail on the Buenos Aires National Wildlife Refuge, Arizona. M.S. Thesis. Univ. Arizona, Tucson, Ariz.

Leopold, A.S. and R.A. McCabe. 1957. Natural history of the Montezuma quail in Mexico. Condor 59:3-26

Marshall, J.T. 1957. The birds of pine-oak woodland in southern Arizona and adjacent Mexico. Pac. Coast Avifauna 32.

Miller, L. 1943. Notes on the Mearns quail. Condor 45: 104-109.

Minckley, W.L. and D.E. Brown. 1994. Wetlands. p. 223-268. In: D.E. Brown, (ed.) Biotic communities: southwestern United States and northwestern Mexico. Univ. Utah Press, Salt Lake City, Ut.

National Oceanic and Atmospheric Administration. 1998. Arizona climatological data. Vol. 102.

National Oceanic and Atmospheric Administration. 1999. Arizona climatological data. Vol. 103.

Neu, C.W., C.R. Byers, and J.M. Peek. 1974. A technique for analysis of utilization- availability data. J. Wildl. Manage. 38:541-545.

Stormer, F.A. 1984. Night roosting habitat of scaled quail. J. Wildl. Manage. 48:191-197.

Stromberg, M.R. 1990. Habitat, movements and roost characteristics of Montezuma Quail in southeastern Arizona. Condor. 45:57-65.

Thomson, W.R. 1975. A photographic technique to quantify lateral cover density. J. South Afr. Wildl. Manage. Assoc. 5:75-78.

Wallmo, O.C. 1954. Nesting of Mearns Quail in southeastern Arizona. Condor 56:125-128.

Zar, J.H. 1984. Biostatistical analysis, Third Edition. Prentice-Hall, Englewood Cliffs, N.J 